Огляди літератури, оригінальні дослідження, погляд на проблему, ювілеї

УдК 616.329-002-06: [616-056.52 + 616.12-008.331.1+616.33-002]

DOI 10.11603/1811-2471.2018.v0.i2.8683

\title{
АКТУАЛЬНІ ПИТАННЯ ДІАГНОСТИКИ ГАСТРОЕЗОФАГЕАЛЬНОЇ РЕФЛЮКСНОї ХВОРОБИ З КОМОРБІДНИМ ПЕРЕБІГОМ У ЗАГАЛЬНОЛІКАРСЬКІЙ ПРАКТИЦІ
}

\author{
ОВ. М. Чернобровий, С. Г. Мелащенко, О. О. Ксенчин, О. І. Черноброва \\ Вінницький національний медичний університет імені М. І. Пирогова
}

РЕЗЮМЕ. Ключовим фактором ризику ГЕРХ на сьогодні вважають ожиріння. Його визнано фактором ризику і есенціальної артеріальної гіпертензії (АГ), і цукрового діабету (ЦД), і первинного остеоартрозу, і ХОЗЛ.

Матеріал і методи. У клініко-діагностичній гастроентерологічній лабораторії ВНМУ імені М. І. Пирогова проводили обстеження хворих на ожиріння та ГЕРХ з гіперлептинемією. За допомогою методики експрес-гастро-рНіндикації вивчали показники рН у двох групах: у хворих на ожиріння та ГЕРХ та у хворих на ГЕРХ з нормальною масою тіла. Спостерігали сталу тенденцію до більшої секреції $\mathrm{HCl}$ у хворих на ожиріння та ГЕРХ.

У дослідженні, проведеному у хворих на ГЕРХ в поєднанні з АГ, ми намагались з'ясувати особливості порушень моторики нижнього стравохідного сфінктера при цих двох захворюваннях. Для цього проводили 3-годинний 3-канальний езофаго-гастро-рН-моніторинг. У хворих на ГЕРХ з АГ та без неї була однакова кількість кислотних та усіх рефлюксів, проте у хворих з супутньою АГ спостерігали більш тривалі найдовші рефлюкси, та загалом кислотна експозиція мала тенденцію до подовження ( $p>0,05)$.

За даними дослідження, яке ми проводили на базі закладів ПМСД м. Вінниці і області у вигляді опортуністичного скринінгу анкет на першому етапі (1431 доросла особа) з подальшим інструментально-лабораторним дообстеженням, було з'ясовано, що 69,72 \% хворих на ГЕРХ (343 особи) мали симптоми шлункової диспепсії. Проведення нелінійного регресійного аналізу впливу факторів ризику показало, що потужним чинником, який налаштовує на патологічний гастроезофагеальний рефлюкс, є ожиріння.

Висновки. Поєднання ГЕРХ з шлунковими диспепсіями (в т.ч. ФД), гіпертензією, надлишковою масою тіла $\epsilon$ поширеним і виявляється у 47,3 \%, 45,45 \% і 63,86 \% обстежених відповідно. У випадку поєднання цих недуг мова йде про очевидну коморбідність. Надмірна маса тіла $\epsilon$ основним фактором коморбідності ГЕРХ з артеріальною гіпертензією, спричиняючи більш інтенсивний рефлюкс, що відображається на збільшенні кислотної експозиції та схильності до тривалих рефлюксів. Додатковий вплив може мати схильність хворих на артеріальну гіпертензію до шлункової гіперацидності.

КЛЮчОВІ СЛОВА: мультиканальний інтралюмінальний езофаго-імпеданс-рН-моніторинг; езофаго-гастрорН-моніторинг; гастроезофагеальна рефлюксна хвороба; ожиріння; артеріальна гіпертензія; функціональна диспепсія.

Вступ. Проблема лікування гастроезофагеальної рефлюксної (ГЕРХ) хвороби $є$ однією з найактуальніших задач сучасної гастроентерології. Це обумовлено значним поширенням даної патології в популяції - 16-20\%, тенденцією до зростання та суттєвим впливом ГЕРХ на якість життя хворих $[1,2]$. Дана категорія пацієнтів не $\epsilon$ однорідною, окрім існування різних морфологічних форм ураження - ерозивні, неерозивні, стравохід Барретта, - значний вплив на клінічний перебіг мають коморбідні захворювання. Фармакопрепарати, які приймає пацієнт з приводу супутньої недуги, можуть впливати на моторику нижнього стравохідного сфінктера, а також вступати у фармакологічну взаємодію з ліками, призначеними для терапії ГЕРX.

Ключовим фактором ризику ГЕРХ на сьогодні вважають ожиріння [3]. Саме з ним більшість гастроентерологів пов'язують глобальне наростання кількості хворих на рефлюксну хворобу. Ожиріння $\epsilon$ визнаним фактором ризику і есенціальної артеріальної гіпертензії (АГ), і цукрового діабету (ЦД), і первинного остеоартрозу, і ХОЗЛ. Йдеться про недуги, надзвичайно поширені у популяції.
Виникнення та прогресування ГЕРХ при ожирінні пов'язані зі збільшенням внутрішньочеревного тиску та експозиції кислоти в стравоході [4], а показники кислотних рефлюксів у осіб з ожирінням корелюють з індексом маси тіла [5]. Цей факт був підтверджений і нами при застосуванні найсучаснішої техніки ідентифікації патологічних рефлюксів - мультиканального інтралюмінального езофаго-імпеданс-рН-моніторингу (МII-рH-M) [6]. Y. Y. Nian зі співавторами також досліджували пацієнтів з ГЕРХ за допомогою MII-pH-М та прийшли до висновку, що ожиріння (IMT 225$)$ й інші чинники можуть збільшувати частоту і тяжкість гастроезофагеальних рефлюксів [7].

За результатами дослідження Abdelkader'a, ожиріння в цілому та абдомінальне ожиріння особливо позначається на клінічній та ендоскопічній тяжкості ГЕРХ [8]. Підвищений рівень гормону лептину пов'язаний з клінічною та ендоскопічною тяжкістю ГЕРХ. Зв'язок абдомінального ожиріння зі стравохідною дисфункцією, збільшенням експозиції кислоти в стравоході та симптомами гастроезофагеального рефлюксу підтвердили також R. Anggiansah'а та M. Aslam'a зі співавторами $[9,10]$. 
Огляди літератури, оригінальні дослідження, погляд на проблему, ювілеї

На думку P. Chang'а та F. Friedenberg, абдомінальне ожиріння, а не IMT, як може здаватися, більш тісно пов'язане з розвитком ускладненого перебігу ГЕPX [11].

Існують суттєві докази, які підтверджують важливу роль підвищення стравохідно-шлункового градієнта тиску, а також продукції медіаторів запалення черевної жирової тканини в патогенезі ГЕРХ, але і досі взаємозв'язок між ожирінням і ГЕРХ залишається не до кінця зрозумілим [12]. Крім того, є підстави вважати, що шляхом втрати маси тіла можна домогтися зменшення симптомів ГЕРХ, але необхідні подальші дослідження, щоб краще зрозуміти точний механізм, за допомогою якого ожиріння сприяє виникненню ГЕРХ. Це допоможе виявити і встановити нові терапевтичні підходи. H. S. Jung також дотримується думки, що ожиріння пов'язано з підвищенням експозиції кислоти у стравоході, а механізм, відповідальний за зв'язок між ГЕРХ та ожирінням, може бути пов'язаний з укороченням довжини нижнього езофагеального сфінктера та збільшенням градієнта гастроезофагеального тиску [13].

Нещодавно М. А. Ливзан та співавтори провели дослідження з метою виявлення особливостей перебігу ГЕРХ, асоційованої з ожирінням та надлишковою масою тіла, на підставі вивчення клінічних, ендоскопічних даних, результатів добового рН-моніторингу та продукції лептину $[14,15]$. Ними було встановлено, що ГЕРХ у хворих на ожиріння та надлишкову масу тіла формується в умовах лептинорезистентності та патології біларного тракту.

Результати 24-годинного езофаго-рН-моніторингу підтвердили, що надмірна маса тіла та ожиріння пов'язані з посиленням рефлюксу, особливо в положенні лежачи [16].

У ретроспективному довготривалому дослідженні 15295 осіб, які проходили медичні огляди, S. K. Park та співавтори виявили, що тільки у пацієнтів із загальним або абдомінальним ожирінням втрата маси тіла чи зменшення окружності талії були пов'язані з поліпшенням симптомів гастроезофагеального рефлюксу [17]. Тому втрата маси тіла або зменшення окружності талії $€$ важливим компонентом лікування у пацієнтів з ожирінням.

Однак існує думка [18], що для вивчення ГЕРХ у пацієнтів з ожирінням слід застосовувати інші, спеціально досліджені значення норми внутрішньостравохідного $\mathrm{pH}$.

Матеріал і методи дослідження. У клінікодіагностичній гастроентерологічній лабораторії ВНМУ імені М. І. Пирогова проводилось обстеження хворих на ожиріння та ГЕРХ з гіперлептинемією (середній показник вмісту лептину склав $(31,86 \pm 4,99)$ нг/мл). За допомогою методики експрес-гастро-рН-індикації (ацидогастрограф АГ-
1рН-М) вивчали показники рН у хворих двох груп: група 1 - хворі на ожиріння та ГЕРХ ( $n=10$, IMT = $(36,98 \pm 3,03))$ та група 2 - хворі на ГЕРХ з нормальною масою тіла $(n=12$, IMT= $(20,99 \pm 0,87))$. При порівнянні показників рН групи 1 та групи 2 були отримані наступні результати: мінімальний $\mathrm{pH}-(1,91 \pm$ $0,17)$ од. $\mathrm{pH}$ проти $(2,09 \pm 0,15)$ од. $\mathrm{pH}(\mathrm{p}>0,05)$, ceреднє арифметичне значення $\mathrm{pH}-(2,93 \pm 0,27)$ од. $\mathrm{pH}$ проти $(3,01 \pm 0,22)$ од. $\mathrm{pH}(\mathrm{p}>0,05)$, медіана $\mathrm{pH}-$ 2,3 од. $\mathrm{pH}$ проти 2,72 од. $\mathrm{pH}$, ФІ рH 3-5 (нормо-гіперацидність) $-(50,0 \pm 10,8) \%$ проти $(33,33 \pm 10,08) \%$

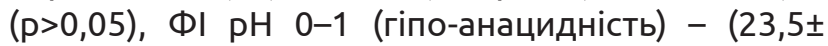
$6,67) \%$ проти $(21,67 \pm 5,07) \%(p>0,05)$. Відмінність між отриманими показниками експрес-гастроpH-індикації в групах 1 та $2 \in$ недостовірною, ймовірно, через невелику кількість досліджень, але спостерігається стала тенденція до більшої секреції $\mathrm{HCl}$ у хворих на ожиріння та ГЕРХ.

Результати й обговорення. В дослідженні, проведеному нами в хворих на ГЕРХ в поєднанні 3 АГ, ми констатували, що обидві недуги $є$ коморбідними і супроводжуються посиленням кислотної агресії [19]. Зважаючи на те, що ожиріння є фактором ризику не тільки ГЕРХ, але і АГ, цікаво було з'ясувати особливості порушень моторики нижнього стравохідного сфінктера при цих двох захворюваннях. Для цього ми проводили 3-годинний 3-канальний езофаго-гастро-рН-моніторинг [20]. Усі пацієнти були поділені на 4 групи, характеристики яких наведені у таблиці 1.

У хворих на ГЕРХ з АГ та без неї була однакова кількість кислотних та усіх (кислотних + некислотних) рефлюксів ( $>>0,05)$. Але відмінність між цими двома групами була в тому, що у хворих із супутньою АГ спостерігались більш тривалі найдовші рефлюкси - $(281,8 \pm 44,7)$ с, проти $(170,1 \pm 28,1)$ с $(p<0,05)$, та в цілому кислотна експозиція мала тенденцію до подовження - $(22,8 \pm 4,7)$ проти $(15,3 \pm 3,6)(p>0,05)$ (табл. 2).

Збільшення перерахованих показників можна пояснити припущенням щодо впливу присутності грижі стравохідного отвору діафрагми або погіршенням механічного та хімічного кліренсу стравоходу після потрапляння в нього рефлюктату. На нашу думку, остання обставина $є$ більш ймовірною. Останнім часом обговорюється значення такого розладу, як неефективна стравохідна моторика (ineffective esophageal motility - IEM), що обтяжує перебіг ГЕРХ [21]. У літературі $\epsilon$ свідчення про негативний вплив домінування симпатичної системи на моторику стравоходу [22]. Враховуючи ту обставину, що у хворих з АГ $є$ гіперсимпатикотонія, стає зрозумілим збільшення показників кислотної експозиції у стравоході. Гіперсимпатикотонія, в свою чергу, тісно пов'язана з підвищеним рівнем лептину та резистентністю до нього при ожирінні [23]. 
Огляди літератури, оригінальні дослідження, погляд на проблему, ювілеї

Таблиця 1. Характеристики груп пацієнтів

\begin{tabular}{|c|c|c|}
\hline \multirow{2}{*}{ АГ } & \multicolumn{2}{|c|}{ ГEPX } \\
\hline & + & - \\
\hline+ & 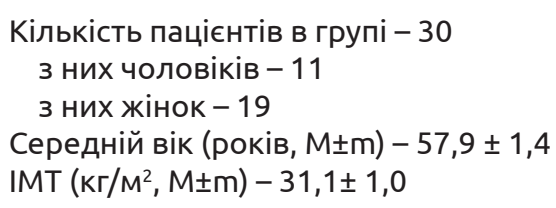 & 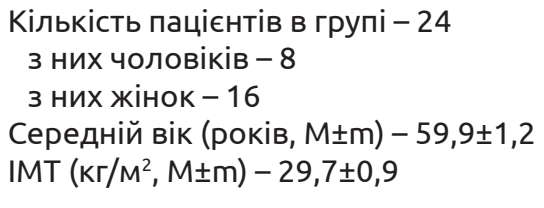 \\
\hline- & 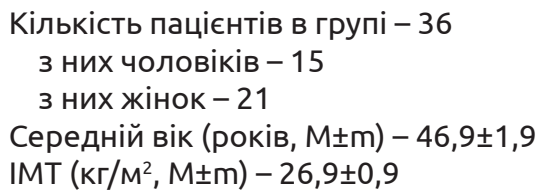 & 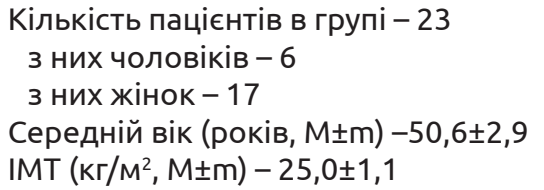 \\
\hline
\end{tabular}

Таблиця 2. Результати 3-годинного 3-канального езофаго-гастро-рН-моніторингу по групах хворих

\begin{tabular}{|c|c|c|c|c|}
\hline Групи пацієнтів & 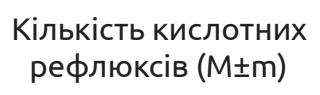 & 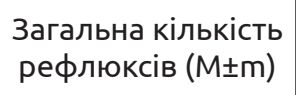 & $\begin{array}{c}\text { Тривалість найдовшого } \\
\text { рефлюксу с, (M } \pm \mathrm{m})\end{array}$ & $\begin{array}{c}\text { \% часу з } \mathrm{pH}<4 \text { в } \\
\text { стравоході }(\mathrm{M} \pm \mathrm{m})\end{array}$ \\
\hline Без ГЕРХ, без АГ & $2,8 \pm 0,8$ & $12,0 \pm 1,5$ & $41,0 \pm 20,1$ & $3,2 \pm 1,9$ \\
\hline ГЕРХ без АГ & $11,6 \pm 1,3$ & $19,1 \pm 1,7$ & $170,1 \pm 28,1 *$ & $15,3 \pm 3,6$ \\
\hline АГ без ГЕРХ & $1,1 \pm 0,5$ & $10,0 \pm 1,3$ & $30,2 \pm 14,5$ & $0,15 \pm 0,14$ \\
\hline ГЕРХ з АГ & $9.9 \pm 1,2$ & $18,2 \pm 1,9$ & $281,8 \pm 44,7 *$ & $22,8 \pm 4,7$ \\
\hline
\end{tabular}

Примітка. *- p <0,05 (між виділеними).

При ГЕРХ частим явищем є поява симптоматики шлункової диспепсії. Це, напевно, є найчастішою коморбідністю при даному захворюванні. Порушення моторики верхніх відділів травної системи і процесів акомодації шлунка, вісцеральна гіперчутливість створюють патофізіологічну основу для формування як синдрому шлункової диспепсії, так і ГЕРХ $[24,25]$. За даними дослідження, яке ми проводили на базі закладів ПМСД м. Вінниці і області у вигляді опортуністичного скринінгу анкет на першому етапі (1431 доросла особа) з подальшим інструментально-лабораторним дообстеженням, було з'ясовано, що 492 опитаних відповідали критеріям ГЕРХ за Монреальським консенсусом 2006 р. [2] та 574 - ФД за Римським консенсусом III. При цьому 69,72 \% хворих на ГЕРХ (343 особи) мали симптоми шлункової диспепсії. У випадку такого поєднання мова йде про очевидну коморбідність, маніфестація якої супроводжувалась більш інтенсивними скаргами на постпрандіальний дискомфорт, епігастральні болі, здуття живота та відрижку повітрям. Проведення нелінійного регресійного аналізу впливу факторів ризику (табл. 3) показало, що на появу диспепсичної симптоматики достовірний вплив мали жіноча стать, наявність супутнього синдрому подразненої товстої кишки, зловживання НПЗП і, звичайно, інфікування Н. piloгу. Потужним фактором, що налаштовує на патологічний гастроезофагеальний рефлюкс, є ожиріння. Якщо серед хворих на диспепсії відсоток осіб з ожирінням та надлишковою масою (IMT>25) був 32,67 \%, то серед хворих на ГЕРХ - 63,86 \% $(p<0,01)$.

Таблиця 3. Результати нелінійного регресійного аналізу залежності (логіт-регресії) диспепсичної та рефлюксної сиптоматики у хворих на ГЕРХ та диспепсію

\begin{tabular}{|c|c|c|c|c|}
\hline \multirow{2}{*}{ Предиктор } & \multicolumn{2}{|c|}{$\begin{array}{c}\text { Диспепсична симптоматика } \\
\text { у хворих на ГЕРХ }\end{array}$} & \multicolumn{2}{|c|}{$\begin{array}{c}\text { Рефлюксна симптоматика } \\
\text { у хворих з диспепсією }\end{array}$} \\
\hline & значення $\mathrm{x}^{2}$ & $p$ & значення $\mathrm{x}^{2}$ & $p$ \\
\hline Вік & 2,076 & 0,10 & 0,837 & N.S. \\
\hline IMT & 0,890 & N.S. & 8,366 & 0,004 \\
\hline H. pilory & 4,143 & 0,02 & 0,004 & N.S. \\
\hline Жіноча стать & 7,478 & 0,01 & 0,511 & N.S. \\
\hline Наявність СПТК & 5,789 & 0,02 & 1,342 & N.S. \\
\hline Зловживання НПЗП & 2,076 & 0,03 & 0,790 & N.S. \\
\hline
\end{tabular}


Огляди літератури, оригінальні дослідження, погляд на проблему, ювілеї

Важливою особливістю ФД $\epsilon$ те, що значна частка таких хворих мають патологічний гастроезофагеальний рефлюкс, але при цьому не мають характерних для ГЕРХ скарг - печії, регургітації, кардіалгії тощо. Основною клінічною маніфестацією в таких пацієнтів є епігастральні болі або дискомфорт. Ми обстежили групу хворих на ФД (96 осіб, середнього віку $(43,2 \pm 1,7)$, в тому числі 27 чоловіків) за допомогою 200-хвилинного мультиканального інтралумінального імпеданс-рНмоніторингу зі стандартизованим сніданком [20]. у 24,0 \% хворих спостерігалося збільшення кількості кислих рефлюксів вище порогового значення (>7 епізодів), що є характерним для ГЕРХ. Додатково ще у 12,5 \% була збільшеною загальна кількість рідинних рефлюксів, що є менш специфічною ознакою, але достовірно вказує на виражені порушення моторики нижнього стравохідного сфінктера. Хворі на ФД з патологічним гастроезофагеальним рефлюксом складають особливу категорію пацієнтів, які формально залишаються з діагнозом диспепсії, але по суті ближчі до ГЕРХ з відповідними особливостями фармакотерапії.

\section{ЛITEPATУPA}

1. Hunt R. World Gastroenterology Organisation Global Guidelines: GERD Global Perspective on Gastroesophageal Reflux Disease / R. Hunt, D. Armstrong, P. Katelaris // J. Clin. Gastroenterol. - 2017. - Vol. 51 (6). - P. 467-478.

2. The Montreal definition and classification of gastroesophageal reflux disease: a global evidence-based consensus / N. Vakil van Zanten, P. Kahrilas, J. Dent [et al.] // Am. J. Gastroenterol. - 2006. - Vol. 101. - P. 1900-1920.

3. Camilleri M. Gastrointestinal complications of щbesity / M. Camilleri, H. Malhi, A. Acosta // Gastroenterology. - 2017. - Vol. 152 (7). - P. 1656-1670.

4. Obesity increases oesophageal acid exposure / H. B. El-Serag, G. A. Ergun, J. Pandolfino [et al.] // Gut. 2007. - Vol. 56. - P. 749-755.

5. Gastroesophageal reflux in asymptomatic obese subjects: An esophageal impedance-pH study / F. Akyüz, A. Uyanıkoglu, F. Ermis [et al.] // World J. Gastroenterol. 2015. - Vol. 21 (10). - P. 3030-3034.

6. Chernobroviy V. Studying the influence of obesity on the motility of the lower esophageal sphincter in patients with gastroesophageal reflux disease and functional dyspepsia, using multichannel intraluminal impedance-pHmonitoring / V. Chernobroviy, S. Melaschenko, O. Ksenchyn // Neurogastroenterology \& motility. - 2015. - Vol. 27, Suppl. 2. - P. 49.

7. Reflux characteristics of 113 GERD patients with abnormal 24-h multichannel intraluminal impedance-pH tests / Y. Y. Nian, Ch. Feng, C. Jing [et al.] // J. Zhejiang Univ-Sci. B. (Biomed. \& Biotechnol). - 2015. -Vol. 16 (9). - P. 805-810.

8. Impact of anthropometric measures and serum leptin on severity of gastroesophageal reflux disease /
Висновки. Поєднання ГЕРХ зі шлунковими диспепсіями (в т.ч ФД), гіпертензією, надлишковою масою тіла $\epsilon$ поширеним і виявляється у 47,3 \%, 45,45 \% і 63,86 \% обстежених відповідно. У випадку поєднання цих недуг мова йде про очевидну коморбідність. У комплексній регресійній моделі виникнення гастроезофагеальної симптоматики у хворих на шлункові диспепсії (в т.ч ФД) найбільше значення має збільшення IMT, при цьому інші фактори (наявність супутнього СПТК, Нрстатус, куріння, стать, вік) мають суттєво менший вплив. Надмірна маса тіла $є$ основним фактором коморбідності ГЕРХ з артеріальною гіпертензією, спричиняючи більш інтенсивний рефлюкс, що відображається на збільшенні кислотної експозиції та схильності до тривалих рефлюксів. Додатковий вплив може мати схильність хворих на артеріальну гіпертензію до шлункової гіперацидності.

Перспективи подальших досліджень. Напрямком пошуку механізмів коморбідності перерахованих нозологій може бути вивчення особливостей шлункової ацидності та моторики нижнього стравохідного сфінктера в залежності від рівня сироваткового лептину, а також чутливості до нього.

N. A. Abdelkader, I. F. Montasser, E. E. Bioumy, W. E. Saad // Dis. Esophagus. - 2015. - Vol. 28 (7). - P. 691-698.

9. Anggiansah R. The effects of obesity on oesophageal function, acid exposure and the symptoms of gastrooesophageal reflux disease / R. Anggiansah, R. Sweis, A. Anggiansahetal // Aliment. Pharmacol. Ther. - 2013. Vol. 37. - P. 555-563.

10. Aslam M. Nonlinear relationship between body mass index and esophageal acid exposure in the extraesophageal manifestations of reflux / M. Aslam, J. C. Slaughter, G. Metal // Clin. Gastroenterol. Hepatol. 2012. - Vol. 10 (8). - P. 874-878.

11. Chang P. Obesity \& GERD / P. Chang, F. Friedenberg // Gastroenterol. Clin. North Am. - 2014. - Vol. 43 (1). P. 161-173.

12. Gastro-esophageal reflux disease and obesity, where is the link? / S. Emerenziani, M. P. Rescio, M. P. L. Guarino [et al.] // World J. Gastroenterol. - 2013. - Vol. 19 (39). P. 6536-6539.

13. Obesity is associated with increasing esophageal acid exposure in Korean patients With Gastroesophageal Reflux Disease Symptoms / H. S. Jung, M. G. Choi, M. K. Baeg [et al.] // J. Neurogastroenterol. Motil. - 2013. - Vol. 19 (3).

14. Ливзан М. А. Гастроэзофагеальная рефлюксная болезнь у лиц с ожирением и лептинорезистентность / М. А. Ливзан, И. В. Лаптева, Т. С. Кролевец // Экспериментальная и клиническая гастроэнтерология. - 2015. № 115 (3). - С. 11-16.

15. Особенности течения гастроэзофагеальной рефлюксной болезни, ассоциированной с ожирением и избыточной массой тела / М. А. Ливзан, И. В. Лапте- 
Огляди літератури, оригінальні дослідження, погляд на проблему, ювілеї

ва, Т. С. Кролевец [и др.] // Терапевтический архив. 2016. - № 88 (2). - С. 21-27.

16. Nocturnal and daytime esophageal acid exposure in normal-weight, overweight, and obese patients with reflux symptoms / J. S. Burgerhart, P. C. van de Meeberg, P. D. Siersema [et al.] // Eur. J. Gastroenterol. Hepatol. 2014. - Vol. 26 (1). - P. 6-10.

17. Weight loss and waist reduction is associated with improvement in gastroesophageal disease reflux symptoms: A longitudinal study of 15295 subjects undergoing health checkups / S. K. Park, T. Lee, H. J. Yang [et al.] // Neurogastroenterol. Motil. - 2016.

18. Normal values of $24 \mathrm{H}$ multichannel intraluminal impedance pH-metry in a Greek obese Population Based on Montreal Definition of Gerd / G. Doulami, S. Triantafyllou, M. Natoudi [et al.] // Obes. Surg. - 2016. - Vol. 26 (1). P. 126-131.

19. Chernobrovy V. GERD: clinical solutions of problems in general practice / V. Chernobrovy, S. Melashchenko, O. Ksenchyn // Wiadomosci Lekarskie. - 2017. - No. 2 P. 327-330.

20. Мелащенко С. Г. Діагностичні можливості 200-хвилинного постпрандіального мультиканального інтралюмінального імпеданс-рН-моніторингу страво-

\section{REFERENCES}

1. Hunt, R., Armstrong, D., Katelaris, P. (2017). World Gastroenterology Organisation Global Guidelines: GERD Global Perspective on Gastroesophageal Reflux Disease. J. Clin. Gastroenterol., 51 (6), 467-478.

2. Vakil van Zanten, N., Kahrilas, P., \& Dent, J. (2006). The Montreal definition and classification of gastroesophageal reflux disease: a global evidence-based consensus. Am. J. Gastroenterol., 101, 1900-1920.

3. Camilleri, M., Malhi, H., \& Acosta, A. (2017). Gastrointestinal complications of obesity. Gastroenterology, 152 (7), 1656-1670.

4. El-Serag, H.B., Ergun, G.A., \& Pandolfino, J. (2007). Obesity increases oesophageal acid exposure. Gut., 56, 749-755.

5. Akyüz, F., Uyanıkoglu, A., \& Ermis, F. (2015). Gastroesophageal reflux in asymptomatic obese subjects: An esophageal impedance-pH study. World J. Gastroenterol., 21 (10), 3030-3034.

6. Chernobroviy, V., Melaschenko, S., \& Ksenchyn, O. (2015). Studying the influence of obesity on the motility of the lower esophageal sphincter in patients with gastroesophageal reflux disease and functional dyspepsia, using multichannel intraluminal impedance-pH-monitoring. Neurogastroenterology \& Motility, 27 (2), 49.

7. Nian, Y.Y., Feng, Ch., \& Jing, C. (2015). Reflux characteristics of 113 GERD patients with abnormal 24-h multichannel intraluminal impedance-pH tests. J. Zhejiang UnivSci. B. (Biomed. \& Biotechnol.), 16 (9), 805-810.

8. Abdelkader, N.A., Montasser, I.F., Bioumy, E.E., \& Saad, W.E. (2015). Impact of anthropometric measures and serum leptin on severity of gastroesophageal reflux disease. Dis. Esophagus, 28 (7), 691-698.

9. Anggiansah, R., Sweis, R., \& Anggiansahetal, A. (2013). The effects of obesity on oesophageal function, ходу порівняно з добовим варіантом / С. Г. Мелащенко, В. М. Чернобровий, О. О. Ксенчин // Гастроентерологія. - 2015. - № 2 (56). - С. 5-11.

21. Lee K. J. Prevalence of ineffective esophageal motility and its relevance to symptoms and esophageal acid exposure in korean patients referred for foregut symptoms / K. J. Lee, J. H. Kim, S. W. Cho // Digestion. - 2006. Vol. 73 (No. 2-3). - P. 171-177.

22. Chen C. L. Cardiac autonomic regulation differentiates reflux disease with and without erosive esophagitis / C. L. Chen, W. C. Orr // Scand. J. Gastroenterol. 2006. - Vol. 41 (No. 9). - P. 1001-1006.

23. Kalil G. Z. Sympathetic nervous system in obesity-related hypertension: mechanisms and clinical implications / G. Z. Kalil, W. G. Haynes // Hypertens. Res. Hypertens. Res. - 2012. - Vol. 35 (1). - P. 4-16.

24. Symptom overlap between postprandial distress and epigastric pain syndromes of the Rome III Dyspepsia Classification / N. Vakil, K. Halling, L. Ohlsson, B. Wernersson // American Journal of Gastroenterology. - 2013. Vol. 108. - P. 767-774.

25. Evidence-based clinical practice guidelines for functional dyspepsia / H. Miwa, M. Kusano [et al.] // J. of Gastroenterology. - 2015. - Vol. 50. - P. 125-139.

acid exposure and the symptoms of gastro-oesophageal reflux disease. Aliment. Pharmacol. Ther., 37, 555-563.

10. Aslam, M., Slaughter, J. C., \& Metal, G. (2012). Nonlinear relationship between body mass index and esophageal acid exposure in the extraesophageal manifestations of reflux. Clin. Gastroenterol.Hepatol., 10 (8), 874-878.

11. Chang, P., \& Friedenberg, F. (2014). Obesity \& GERD. Gastroenterol. Clin. North Am., 43 (1), 161-173.

12. Emerenziani, S., Rescio, M.P., \& Guarino, M.P.L. (2013). Gastro-esophageal reflux disease and obesity, where is the link? World J. Gastroenterol., 19 (39), 6536-6539.

13. Jung, H.S., Choi, M.G., \& Baeg, M.K. (2013). Obesity is associated with increasing esophageal acid exposure in Korean patients with gastroesophageal reflux disease symptoms. J. Neurogastroenterol. Motil., 19 (3).

14. Livzan, M.A., Lapteva, I.V., \& Krolevets, T.S. (2015). Gastroezofagealnaya reflyuksnaya bolezn u lits s ozhireniyem i leptinorezistentnost [Gastroesophageal reflux disease in obese persons and leptin resistance]. Eksperimentalnaya i klinicheskaya gastroyenterologiya - Experimental and Clinical Gastroenterology, 115 (3), 11-16 [in Russian].

15. Livzan, M.A., Lapteva, I.V., \& Krolevets, T.S. (2016). Osobennosti techeniya gastroezofagealnoy reflyuksnoy bolezni, assotsiirovannoy s ozhireniyem i izbytochnoy massoy tela [Features of the course of gastroesophageal reflux disease associated with obesity and overweight]. Terapevticheskiy arkhiv - Therapeutic Archive, 88 (2), 21-27.

16. Burgerhart, J.S., van de Meeberg, P.C., \& Siersema, P.D. (2014). Nocturnal and daytime esophageal acid exposure in normal-weight, overweight, and obese patients with reflux symptoms. Eur. J. Gastroenterol. Hepatol., $26(1), 6-10$.

17. Park, S.K., Lee, T., \& Yang, H.J. (2016). Weight loss and waist reduction is associated with improvement in 
Огляди літератури, оригінальні дослідження, погляд на проблему, ювілеї

gastroesophageal disease reflux symptoms: A longitudinal study of 15295 subjects undergoing health checkups. Neurogastroenterol. Motil.

18. Doulami, G., Triantafyllou, S., \& Natoudi, M. (2016). Normal values of $24 \mathrm{H}$ multichannel intraluminal impedance $\mathrm{pH}$-metry in a Greek obese population based on Montreal definition of Gerd. Obes Surg., 26 (1), 126-131.

19. Chernobrovy, V., Melashchenko, S., \& Ksenchyn, O. (2017). GERD: clinical solutions of problems in general practice. Wiadomosci Lekarskie, 2, 327-330.

20. Melashchenko, S.H., Chernobrovyi, V.M., \& Kenschin, O.O. (2015). Diahnostychni mozhlyvosti 200-khvylynnoho postprandialnoho multykanalnoho intraliuminalnoho impedans-rN-monitorynhu stravokhodu porivniano z dobovym variantom [Diagnostic possibilities of 200 -minute postprandial multicanal intraluminal impedance-pH monitoring of the esophagus compared to the daily option]. Hastroenterolohiia - Gastroenterology, 2 (56), 5-11 [in Ukrainian].
21. Lee, K.J., Kim, J.H., \& Cho, S.W. (2006). Prevalence of ineffective esophageal motility and its relevance to symptoms and esophageal acid exposure in korean patients referred for foregut symptoms. Digestion, 73 (2-3), 171-177.

22. Chen, C.L., \& Orr, W.C. (2006). Cardiac autonomic regulation differentiates reflux disease with and without erosive esophagitis. Scand. J. Gastroenterol., 41 (9), 10011006.

23. Kalil, G.Z., \& Haynes, W.G. (2012). Sympathetic nervous system in obesity-related hypertension: mechanisms and clinical implications. Hypertens. Res. Hypertens. Res., 35 (1), 4-16.

24. Vakil, N., Halling, K., Ohlsson, L., \& Wernersson, B. (2013). Symptom overlap between postprandial distress and epigastric pain syndromes of the Rome III Dyspepsia Classification. American Journal of Gastroenterology, 108, 767-774.

25. Miwa, H., \& Kusano, M. Evidence-based clinical practice guidelines for functional dyspepsia. J. of Gastroenterology, 50, 125-139.

\title{
АКТУАЛЬНЫЕ ВОПРОСЫ ДИАГНОСТИКИ ГАСТРОЭЗОФАГЕАЛЬНОЙ РЕФЛЮКСНОЙ БОЛЕЗНИ С КОМОРБИДНЫМ ТЕЧЕНИЕМ В ОБЩЕВРАЧЕБНОЙ ПРАКТИКЕ
}

\author{
๑В. Н. Чернобровый, С. Г. Мелащенко, О. А. Ксенчин, Е. И. Чернобровая \\ Винницкий национальный медицинский университет имени Н. И. Пирогова
}

РЕЗЮМЕ. Ключевым фактором риска ГЭРБ сегодня является ожирение. Оно считается признанным фактором риска и эссенциальной артериальной гипертензии (АГ), и сахарного диабета (СД), и первичного остеоартроза, и ХОБЛ.

Материал и методы. В клинико-диагностической гастроэнтерологической лаборатории ВНМУ имени Н. И. Пирогова проводили обследование больных с ожирением и ГЭРБ с гиперлептинемией. С помощью методики экспресс-гастро-рН-индикации изучали показатели рН в двух группах: у больных ожирением и ГЭРБ и у больных ГЭРБ с нормальной массой тела. Наблюдали устойчивую тенденцию к большей секреции HCl у больных ожирением и ГЭРБ.

В исследовании, проведенном нами у больных ГЭРБ в сочетании с АГ, мы пытались выяснить особенности нарушений моторики нижнего пищеводного сфинктера при этих двух заболеваниях. Для этого мы проводили 3-часовой 3-канальный эзофаго-гастро-рН-мониторинг. У больных ГЭРБ с АГ и без нее было одинаковое количество кислотных и всех рефлюксов, однако у больных с сопутствующей АГ наблюдались более длительные длинные рефлюксы, и в целом кислотная экспозиция имела тенденцию к увеличению $(p>0,05)$.

По данным исследования, которое проводилось нами на базе учреждений ПМСП в Виннице и области в виде оппортунистического скрининга анкет на первом этапе (1431 человек) с последующим инструментально-лабораторным дообследованием, было выяснено, что 69,72 \% больных ГЭРБ (343 человека) имели симптомы желудочной диспепсии. Проведение нелинейного регрессионного анализа влияния факторов риска показало, что мощным фактором, который настраивает на патологический гастроэзофагеальный рефлюкс, является ожирение.

Выводы. Сочетание ГЭРБ с желудочными диспепсиями (в т.ч ФД), гипертензией, избыточной массой тела является распространенным и выявляется в 47,3 \%, 45,45 \% и 63,86 \% обследованных соответственно. В случае объединения этих недугов речь идет об очевидной коморбидности. Избыточная масса тела является основным фактором коморбидности ГЭРБ с артериальной гипертензией, вызывая более интенсивный рефлюкс, что отражается на увеличении кислотной экспозиции и склонности к длительным рефлюксам. Дополнительное влияние может иметь склонность больных артериальной гипертензией к желудочной гиперацидности.

КЛЮЧЕВЫЕ СЛОВА: мультиканальный интралюминальный эзофаго-импеданс-рН-мониторинг; эзофагогастро-рН-мониторинг; гастроэзофагеальная рефлюксная болезнь; ожирение; артериальная гипертензия; функциональная диспепсия. 


\section{Огляди літератури, оригінальні дослідження, погляд на проблему, ювілеї}

\section{ACTUAL ISSUES OF THE DIAGNOSTICS OF GASTROESOPHAGEAL REFLUX DISEASE WITH COMORBIDITY IN GENERAL PRACTICE}

\section{@V. M. Chernobroviy, S. G. Melaschenko, O. O. Kenshyn, O. I. Chernobrova \\ M. Pyrohov Vinnytsia National Medical University}

SUMMARY. A key risk factor for GERD is obesity today. Obesity is a recognized risk factor for essential hypertension (AG), and diabetes mellitus (DM), and primary osteoarthritis, and COPD.

Material and Methods. In the clinic-diagnostic gastroenterological laboratory of VNMU named by M. Pyrohov was examined for patients with obesity and GERD with hyperleptinemia. Using the method of express-gastro-pH indication, $\mathrm{pH}$ parameters were studied in two groups of patients: obese and GERD patients, and patients with GERD with normal body mass. There has been a tendency towards greater $\mathrm{HCl}$ secretion in obese and GERD patients.

In a study conducted by us in patients with GERD in conjunction with hypertension, we tried to find out the features of lower esophageal sphincter motor disorders in these two diseases. To do this we conducted a 3-hour, 3-channel esophago-gastro-pH-monitoring. Patients with GERD with and without hypertension had the same amount of acid and all reflux, however, patients with concomitant hypertension had longer longest refluxes, and overall, acid exposure tended to lengthen ( $p>0.05)$.

According to the research conducted by us in the form of opportunistic screening in the first stage (1431 adults), followed by instrumental and laboratory examination, it was found that $69.72 \%$ of GERD patients (343 persons) had symptoms of gastric dyspepsia. Conducting a nonlinear regression analysis of the influence of risk factors showed that obesity is a powerful factor adjusting to pathological gastroesophageal reflux.

Conclusions. The combination of GERD with gastric dyspepsia (including FD), hypertension and overweight is common and is found in $47.3 \%, 45.45 \%$ and $63.86 \%$ of the examined patients respectively. In the case of a combination of these ailments, it is an obvious comorbidity. Excessive body mass is the main factor of comorbidity of GERD with arterial hypertension, causing more intense reflux, which affects the increase of acid exposure and propensity to prolonged reflux. An additional effect may be the tendency of patients with arterial hypertension to excessive acidity of the stomach.

KEY WORDS: multicanal intraluminal esophageal impedance-pH-monitoring; esophagogastro-pH-monitoring; gastroesophageal reflux disease; obesity; arterial hypertension; functional dyspepsia.

Отримано 12.02 .2018 